\title{
Lithostratigraphical subdivision of the Sherwood Sandstone Group (Triassic) of the north- eastern part of the Carlisle Basin, Cumbria and Dumfries and Galloway, UK.
}

\author{
D.W. HollidaY ${ }^{1,3}$, N.S. JONES ${ }^{1,4}$ \& A.A. MCMillan ${ }^{2}$ \\ ${ }^{1}$ British Geological Survey, Kingsley Dunham Centre, Keyworth, Nottingham, NG12 5GG, UK \\ ${ }^{2}$ British Geological Survey, Murchison House, West Mains Road, Edinburgh, EH9 3LA, UK \\ ${ }^{3}$ Present address: 10 Tarn Court, Ilkley, West Yorkshire, LS29 8UE, UK \\ ${ }^{4}$ Present address: Saudi Aramco, PO Box 4442, Ras Tanura 31311, Saudi Arabia
}

\section{Synopsis}

Two formations, the St Bees Sandstone and Kirklinton Sandstone, have been mapped in the past within the Triassic Sherwood Sandstone Group of the eastern part of the Carlisle Basin, Cumbria, and adjacent parts of Dumfries and Galloway, UK. However, previous workers have found considerable difficulty in consistently identifying, defining and mapping the Kirklinton Sandstone Formation. The principal lithological change within the Sherwood Sandstone Group is between mainly fine-grained sandstones, that are commonly micaceous and contain numerous mudstone interbeds in the lower and middle parts of the group. Fine- to coarse-grained sandstones with rare or no mica and few mudstone partings occur at the top of the group. This change occurs within the Kirklinton Sandstone Formation as previously mapped. Several options are considered as to how the group should be lithostratigraphically subdivided and the nomenclature to be adopted. All options presently have some associated problems, but, in view of the recently determined similarities with the contiguous sandstones offshore, the adoption of the same terminology as in the adjacent East Irish Sea and Solway Firth basins is suggested, i.e. 
St Bees Sandstone Formation below (subdivided where possible into Rottington Sandstone and Calder Sandstone members) and Ormskirk Sandstone Formation above.

\section{Introduction}

Current lithostratigraphical subdivision of Triassic rocks in Britain follows the framework established by Warrington et al. (1980). The terms in common usage prior to those proposals, such as 'Bunter', 'Keuper' and 'Rheatic' had acquired mixed litho- and chronostratigraphical connotations. The Warrington et al. (1980) scheme avoids the use of such names and clearly separates lithostratigraphical and chronostratigraphical divisions. They (op. cit., p. 13) proposed the term Sherwood Sandstone Group (SSG) broadly to encompass arenaceous "formations previously assigned to the 'Bunter' and the arenaceous (lower) part of the 'Keuper' in Britain". The 'Bunter' and 'Keuper' rocks are thought to be separated by a widespread hiatus, the Hardegsen Disconformity. The SSG is overlain by the dominantly argillaceous beds of the Mercia Mudstone Group (MMG). Where argillaceous beds rest on the disconformity, the junction between the two groups is likely to be sharp, but, where arenaceous rocks of the SSG (such examples were formerly called Keuper Sandstone) occur above the Hardegsen surface, the boundary between the groups is likely to be gradational and diachronous (Warrington et al. 1980).

Prior to the Warrington et al. (1980) nomenclature, the arenaceous part of the Triassic succession in Cumbria, including the Carlisle and Vale of Eden basins and the eastern margin of the East Irish Sea Basin, was largely assigned to a single division, the St Bees Sandstone (Figs 1, 2; Tables 1, 2) (Harkness 1862; Dixon et al. 1926; Eastwood 1930; Eastwood et al. 1931; Trotter \& Hollingworth 1932; Trotter et al. 1937; Arthurton \& Wadge 1981). A higher unit, the Kirklinton Sandstone (Holmes 1881, 1899; Dixon et al. 1926; Trotter \& Hollingworth 1932; Day 1970) was 
also recognised in the Carlisle Basin (Table 1). As reviewed below, the status of the Kirklinton Sandstone, whether it can be recognised in other areas, and its relationship to both the St Bees Sandstone and the overlying strata, have been called into question. Notwithstanding these difficulties, Arthurton et al. (1978) and Warrington et al. (1980, table 4 column 7) included the St Bees and Kirklinton sandstones as component formations of the SSG in the Carlisle Basin.

Since 1980, much new information has become available relating to the lithostratigraphy and sedimentology of the SSG of Cumbria and adjacent areas (Tables 1-3). This is particularly the case in the East Irish Sea Basin (EISB), the Solway Firth Basin (SFB) and other offshore areas, following extensive hydrocarbon exploration (Colter 1997; Jackson et al. 1995; Quirk et al. 1999; Chadwick et al. 2001) and the onshore investigation of the area around Sellafield, west Cumbria, as a potential repository or store site for radioactive waste (Michie \& Bowden 1994; Bowden et al. 1998). As a result, a more detailed subdivision of the SSG is now employed in these areas (Tables 1-3). However, the relationship between this more recently proposed lithostratigraphy in the EISB and the older subdivisions elsewhere in Cumbria remains uncertain. In particular, the age, stratigraphical relations and correlation of the Kirklinton Sandstone have not been resolved. In this account, we review the existing nomenclature for the SSG in Cumbria, the offshore East Irish Sea and SW Scotland. Reconnaissance field investigations of the key exposures of the SSG in NE Cumbria and adjacent areas of Dumfries and Galloway were carried out, including the eponymous area of the Kirklinton Sandstone (Holliday et al., 2005). The local and regional lithostratigraphical implications of the field observations and present recommendations for the subdivision of the SSG of the Carlisle Basin are also discussed.

\title{
Previous investigations
}

\author{
The Carlisle Basin
}


Though extensively concealed by Quaternary deposits, the Permo-Triassic (New Red Sandstone) rocks of the Carlisle Basin attracted considerable interest during the 19th century. The principal contributions during this period are listed by Dixon et al. (1926, pp. 103-105). The stratigraphical order, classification and structural relationships of the various argillaceous, evaporitic and arenaceous units observed at outcrop and in boreholes were matters of considerable debate. These were not satisfactorily resolved until the publication of the 2 nd edition of the Carlisle Memoir (Dixon et al. 1926) (Table 1), and confirmed by the Silloth 1-A Borehole (Fig. 3), drilled in 1973 by Ultramar Exploration. In this borehole, the SSG was proved to be $502 \mathrm{~m}$ thick $(381-883 \mathrm{~m})$.

The 'red sandstone of St Bees Head' was well known to early workers, e.g. Sedgwick (1836). The first use of the term St Bees Sandstone seems to have been by Harkness (1862) and Murchison \& Harkness (1864) in the area around St Bees Head, west Cumbria, and was quickly applied elsewhere in NW England to lithologically similar correlatives. The distinctive sandstone lithofacies seen on the coast and in quarries around St Bees can also be recognised in west and south Cumbria, and the Carlisle and Vale of Eden basins. The name Annan Sandstone was introduced by Horne \& Gregory (1916) for the sandstone in the Scottish part of the Carlisle Basin. However, the continuity of outcrop with the St Bees Sandstone immediately across the border in England and offshore in the Solway Firth Basin led Barrett (1942) and later workers, other than Brookfield (2004), to discontinue its use. Brookfield considered that stratigraphical terminology for separate basins and areas should remain distinct (Table 1). The St Bees Sandstone is typically fine- to medium-grained, with rare, locally-derived angular mudstone ripup clasts. Siltstone and claystone partings are common in its lower part, which is gradational with underlying argillaceous rocks of the St Bees or Eden Shales (Dixon et al. 1926; Trotter \& Hollingworth 1932; Holliday et al. 2001; Brookfield 2004). 
Holmes $(1881,1899)$ proposed that another sandstone unit, the Kirklinton Sandstone, softer and less well-cemented, and commonly with medium to coarse, rounded sand grains, was present in the Carlisle Basin, unconformably overlying the St Bees Sandstone (Table 1). Goodchild (1893) observed some lithological similarities between parts of the Kirklinton Sandstone and the Waterstones (Keuper) of the English Midlands. However, the St Bees Sandstone and Kirklinton Sandstone were later shown to be essentially conformable and the latter was seen by many as only a local lithofacies variation of the upper part of the St Bees Sandstone. This was because the two lithofacies types apparently alternated at many localities (e.g. Gregory 1915b; Dixon et al. 1926; Trotter \& Hollingworth 1932; Barrett 1942). It is difficult to understand from the written accounts and surviving fieldmaps the reasons why Holmes $(1881,1899)$ included some exposures within the Kirklinton Sandstone, rather than St Bees Sandstone. Trotter \& Hollingworth (1932, p. 141) suggested that there was little justification for retaining the term Kirklinton Sandstone except as a means of broadly separating the generally stratigraphically higher, softer and less well-cemented sandstones. Thus, although the Geological Survey maps of the eastern Carlisle Basin show the Kirklinton Sandstone and St Bees Sandstone as separate lithostratigraphical units (Dixon et al. 1926; Trotter \& Hollingworth 1932; Day 1970), the bipartite subdivision was not continued into the western part of the basin due to poor exposure (British Geological Survey 1995, 1997, 1998).

In west Cumbria (Eastwood et al. 1931; Trotter et al. 1937) and the Vale of Eden (Arthurton \& Wadge 1981), the SSG was shown on the published geological maps as comprising only an undivided St Bees Sandstone (Table 2). Even though rocks of Kirklinton Sandstone-type lithofacies are exposed in these areas, it was argued that the inferred diachronous and gradational boundary between the divisions could not be adequately and consistently mapped in the field because of local structural complexity and the relatively thick and persistent drift cover. Some attempts were made to extend the use of the term Kirklinton Sandstone for the higher, less well- 
cemented sandstones in these areas, e.g. Gregory (1915a) in west Cumbria and Goodchild (1893) in the Vale of Eden, but were supported by few workers (Tables 2, 3).

Recently, Brookfield (2004) has revived the term Annan Sandstone in the Carlisle Basin and applied it, for the first time, to the English outcrops (Table 1). Though not explicitly stated, his Annan Sandstone apparently is not strictly used in its original (Horne \& Gregory 1916) sense, and not only comprises strata previously regarded as St Bees Sandstone, but also includes beds previously mapped by Holmes (1899), Dixon et al. (1926) and Trotter \& Hollingworth (1932) as forming the lower part of the Kirklinton Sandstone and 'transitional strata'. The Kirklinton Sandstone is retained by Brookfield (2004) but used, in a more restricted sense, for only the higher parts of the formation as previously recognised. No type sections were designated by Brookfield (2004) for either the Annan Sandstone or the revised Kirklinton Sandstone.

The Kirklinton Sandstone (sensu Holmes 1899) is overlain in the Carlisle Basin by the Stanwix Shales, previously regarded as part of the 'Keuper Series' and now taken as a component part of the MMG. The top of the Kirklinton Sandstone was thought by Holmes $(1891,1899)$ to be at an unconformity. However, Dixon et al. (1926) and Trotter \& Hollingworth (1932) interpreted the field evidence as indicating a gradational junction.

East Irish Sea and Solway Firth basins and west Cumbria

There is a much greater understanding of the lithostratigraphy of the SSG in the areas offshore to Cumbria (Table 2), derived from the analysis of borehole cores and cuttings, down-hole geophysical logs and seismic reflection profiles. These data were obtained during the exploration for oil and gas in the EISB beginning in the 1970s and continuing to the present day (Colter \& Barr 1975; Colter 1978, 1997; Ebbern 1981; Burley 1984; Bushell 1986; Jackson et al. 1987; 
Jackson \& Johnson 1996). This has led to the fully formalised lithostratigraphical scheme of Jackson \& Johnson (1996) that has been extended to much of the northern part of the Irish Sea, including the Solway Firth Basin (Chadwick et al. 2001) (Tables 2, 3). Detailed sedimentological studies have helped to differentiate the subdivisions of the SSG offshore (Meadows \& Beach 1993a, 1993b; Cowan 1993; Cowan et al. 1993). Much of the St Bees Sandstone Formation offshore comprises the deposits of a major northwards flowing river system in a semi-arid continental setting, but aeolian deposition became increasingly important in the higher part of the formation, particularly towards the basin margins. The Rottington Sandstone Member is almost everywhere of fluvial origin, whereas the Calder Sandstone Member commonly exhibits alternating fluvial and aeolian facies. Offshore in the East Irish Sea the Ormskirk Sandstone Formation also contains the deposits of a major river system, subjected to periodic aeolian deposition, particularly towards the basin margin and across interfluves.

Essentially the same lithostratigraphical units were recognised onshore in west Cumbria by Barnes et al. (1994) (see also Jones \& Ambrose 1994; Akhurst et al. 1997; British Geological Survey 1999) from the study of outcrops and by the examination of the more complete sections provided by the several kilometres of core from boreholes drilled around Sellafield (Michie \& Bowden 1994). However, some different names and a different hierarchy were proposed, principally because the Calder Sandstone Formation in this area was noticeably coarser grained than either the St Bees or the Ormskirk Sandstone formations, or its offshore equivalent, the Calder Sandstone Member (Tables 2, 3). As offshore, the onshore subdivisions of the SSG in west Cumbria can be characterised by their differing sedimentological origins (Jones \& Ambrose 1994). The onshore deposits form part of the same northwards flowing fluvial system as offshore, but aeolian deposition is of much greater significance, particularly in the upper half. The St Bees Sandstone is almost totally of fluvial origin with only rare $(<1 \%)$ aeolian interbeds. In contrast, the Calder Sandstone and Ormskirk Sandstone formations largely comprise aeolian 
deposits with, in the Calder Sandstone, some notable fluvial interbeds. Onshore, the boundary between the Calder and Ormskirk Sandstones is taken at the top of a prominent, persistent fluvial unit (Barnes et al. 1994).

The borehole cores, geophysical logs and seismic reflection data indicate that the boundaries between the three divisions of the SSG, are sharp and laterally persistent, both onshore and offshore in the EISB. Barnes et al. (1994) (also Jackson et al. 1995; Jackson \& Johnson 1996) suggested that these boundaries are disconformities, the uppermost corresponding to the Hardegsen Disconformity. These observations contradicted the previous investigations of Eastwood et al. (1931) and Trotter et al. (1937) who concluded that there were no major breaks in the sequence and that the aeolian beds are a local lithofacies of the fluvial rocks and cannot be separately mapped at surface. The alternations of facies cited by these authors in support of their case can now be identified within the Calder Sandstone, particularly in its lower part, where such alternations are common (Barnes et al. 1994, fig. 1; Jones \& Ambrose 1994; Jackson \& Johnson 1996; Chadwick et al. 2001).

\section{Correlation between the East Irish Sea and Carlisle basins}

Barnes et al. (1994, pp. 58-59, fig. 2) discussed the correlation of their west Cumbrian SSG succession with those of other parts of Cumbria, in particular with the Carlisle and Vale of Eden basins. They (see also Jackson et al. 1995 and Jackson \& Johnson 1996) noted that the mud log and geophysical logs of the Silloth No. 1-A Borehole provided the basis for the recognition of the equivalents of the offshore and west Cumbria subdivisions (Fig. 3). The four subdivisions of the offshore Calder Sandstone Member, CR1 to CR4, based principally on the study of wireline logs and depositional environment analyses, can also be recognised onshore in the Sellafield and Silloth No. 1-A boreholes. Seismic reflection data indicate that the correlatives of the west 
Cumbrian and offshore SSG divisions can be mapped in the subsurface of the Carlisle Basin away from the Silloth No. 1A Borehole (Chadwick et al. 1995, fig. 38; Akhurst et al. 1997, fig. 28; Holliday et al. 2004) (Table 1). Barnes et al. (1994) drew attention to the records of similar 'St Bees Sandstone' and 'Kirklinton Sandstone type facies alternations in the SSG of the Vale of Eden (Arthurton \& Wadge 1981), suggesting the possible presence here also of equivalents of the Calder Sandstone and, perhaps, the Ormskirk Sandstone Formation.

However, it is presently uncertain how the Calder Sandstone and the Ormskirk Sandstone formations correspond, with the formations mapped at outcrop in the Carlisle and Vale of Eden basins (Table 3), and several alternative proposals have been made. Barnes et al. (1994) broadly correlated the Ormskirk Sandstone and Kirklinton Sandstone, and compared the 'transitional' interbedding of St Bees Sandstone and Kirklinton Sandstone-type strata, described by Dixon et al. (1926), with the alternating fluvial and aeolian facies of the Calder Sandstone Formation around Sellafield. Jackson et al. (1995) and Jackson \& Johnson (1996, p. 70) proposed that the Ormskirk Sandstone Formation "corresponds approximately" with the Kirklinton Sandstone of the Carlisle area, whereas Chadwick et al. (2001) suggested that the Kirklinton Sandstone includes equivalents of both the Calder Sandstone Member and the Ormskirk Sandstone Formation.

The current problems of lithostratigraphical division in Cumbria result principally from the uncertain nature and status of the Kirklinton Sandstone and reflect the lack of modern information on the sequence, lithology and sedimentology of the formation at outcrop in the Carlisle and Vale of Eden basins. Key questions include:

- Is the Kirklinton Sandstone Formation a valid lithostratigraphical division and can it be adequately defined and distinguished from the St Bees Sandstone? 
- Can the Calder Sandstone Member (or Calder Sandstone Formation) and Ormskirk Sandstone lithofacies be recognised in the outcrops previously referred to the Kirklinton Sandstone?

- Can the basal Calder Sandstone Formation and Ormskirk Sandstone Formation disconformities be recognised within the inferred equivalent strata at outcrop?

- Which if any of these divisions constitute mappable formations at the surface in the Carlisle Basin as well as in the subsurface?

\section{Field investigations}

In an attempt to answer the above questions, some of the more accessible outcrops of the SSG to the north and east of Carlisle, around Annan, Longtown, Brampton and Canonbie, have been examined (Fig. 2), including the eponymous locality for the Kirklinton Sandstone (Holmes 1881, 1889; Dixon et al. 1926; Trotter \& Hollingworth 1932; Barrett 1942; Day 1970). Comparison was made between the lithology and sedimentology of the sandstones in this area and that of the SSG in west Cumbria (Jones \& Ambrose 1994; Akhurst et al. 1997) and in adjacent offshore areas (Jackson \& Johnson 1996; Chadwick et al. 2001).

\section{St Bees Sandstone Formation}

The St Bees Sandstone Formation is exposed in several quarries and natural exposures in north Cumbria, and eastern Dumfries and Galloway (Dixon et al. 1926). The lower part of the formation and the transition to the underlying Eden Shales are seen in sections in the Kirtle Water and quarries at Cove [NY 265 704] and Corsehill [NY 206 702] near Kirkpatrick Fleming in southern Scotland (Horne \& Gregory 1916; Barrett 1942; Brookfield 2004). The higher parts of the formation are present in the complete and continuous exposures in the cliffs and quarries on the sides of the River Gelt gorge, c. 2-3 km south of Brampton (Trotter \& Hollingworth 1932). Other important sections occur in Carwinley Burn (Dixon et al. 1926; Trotter \& 
Hollingworth 1932), at or near the top of the St Bees Sandstone, where the stream is crossed by the Longtown-Penton road [NY 407 732] (Dixon et al. 1926; Day 1970).

Cove Quarry [NY 254 710] exposes c. $35 \mathrm{~m}$ of the lower part of the St Bees Sandstone (Figs 4, 5). A detailed sedimentary log was given by Brookfield (2004). The sandstones are typically reddish-brown, fine-grained or fine- to medium-grained, micaceous, subfeldspathic-arenites (Fig. 6). In the lower part of the quarry, sheet sandstones are interbedded with laterally continuous mudstones with desiccation cracks. Trough and planar tabular cross-bedding and ripple crosslamination are the main sedimentary structures with planar lamination, rip-up clasts, ripple form sets, load casts and possible annelid tracks also common features. The facies present include sheetflood sandstones, playa mudstones and minor channel sandstones. Palaeocurrent readings from these structures indicate a unidirectional flow towards the north-west and west-north-west. In the upper part of the quarry, the sandstones are thicker bedded, and more channelised, with overbank playa mudstone becoming less common and much less persistent. Similar facies (sheetflood sandstones, playa mudstones and minor channel sandstones) also occur in Corsehill Quarry nearby [NY 206 702].

Extensive quarry sections, each typically up to $25 \mathrm{~m}$ in thickness, in the gorge of the River Gelt, e.g. [NY 5287 5864], reveal sandstones of similar lithology and sedimentological character to those towards the top of Cove Quarry (Fig. 7). Thick bedded (commonly $>1 \mathrm{~m}$ ), reddish brown, cross-bedded, fine- to medium-grained, micaceous, fluvial channel sandstones, are dominant with only rare mudstones. Laterally persistent (tens to hundreds of metres) erosion surfaces form prominent features of these quarries and are the products of scour along channel bases (Fig. 7). Palaeocurrents again suggest flow towards the north-west and west-north-west.

The overall lithological and sedimentological characters of the beds seen at these and other localities are closely comparable with those of the of the St Bees Sandstone in the outcrops at the 
type locality of the formation near St Bees, west Cumbria, and in the nearby Nirex boreholes at Sellafield (Barnes et al. 1994; Jones \& Ambrose 1994). The same characters are found in the offshore Rottington Sandstone Member (Jackson \& Johnson 1996). The dominance of sheetflood sandstones over minor channel sandstones in the lower part of the formation at Cove and Corsehill quarries suggests that the beds there belong to a sheetflood facies association, similar to, or part of that recognised in the lower part of the St Bees Sandstone Formation (North Head Member) in west Cumbria by Jones \& Ambrose (1994) and Akhurst et al. (1997). This facies association has been interpreted as part of a terminal fan deposit, which was overlain by a northward advancing sandy braidplain comprising the bulk of the St Bees Sandstone, as seen at the top of Cove Quarry and in the River Gelt. The latter are comparable with the fluvial channel facies association of the St Bees Sandstone in west Cumbria and the EISB (Jones \& Ambrose 1994; Jackson \& Johnson 1996; Akhurst et al. 1997), and most likely formed part of the same northerly or north-westerly flowing braided fluvial system. The St Bees Sandstone is dominated by fluvial channel facies. Muddy floodplain sediments are indicated by the presence locally of thin mudstone partings. These were extensively reworked and mudflake breccias are common suggesting that this lithology was widespread.

\section{Lower part of the Kirklinton Sandstone Formation}

Strata, previously mapped (Holmes 1899; Dixon et al. 1926; Trotter \& Hollingworth 1932) as occurring in the lower part of the Kirklinton Sandstone Formation, crop out in several stream and river sections. Although of similar grain size and petrological character to the St Bees Sandstone Formation, these rocks generally contain less mica. Many beds are soft and not as well cemented and this restricted their use as building stone and is reflected in the lack of quarries in this part of the outcrop.

Around $15 \mathrm{~m}$ of very fine to medium-grained sandstone is exposed in the River Lyne [NY 431 677 to 432675$]$ to the WNW of the ruined Kirklinton Hall. A conspicuous feature here is the 
presence of numerous laterally continuous, subhorizontal bedding surfaces (Fig. 8). Facies variations are subtle and are particularly difficult to recognise in the cliff sections in poor exposure or difficult light conditions. The rock platforms at or near river level are commonly more informative. Both fluvial (sandflat) and probable aeolian (sandsheet) facies are present, but large aeolian dune sets are apparently absent. The fluvial facies comprises fine-grained, reddish brown, micaceous subfeldspathic-arenite sandstones with well-defined flaggy lamination, ripple cross-lamination and ripple form sets suggesting flow towards the WNW (Fig. 9). These are interpreted as sandflat deposits. Interbedded are softer and less well cemented, moderately to well sorted, moderately to well-rounded, fine to medium-grained, orange-brown to reddishbrown subfeldspathic-arenite sandstones in beds ranging from $2-5 \mathrm{~cm}$ thick. Mica is rare or absent. Low angle cross-bedding and adhesion ripples are common (Figs 10, 11). These beds are interpreted as sandsheet deposits. Associated with this facies are some interbedded siltstones and mudstone laminae showing desiccation cracks.

Sandsheets and sandflats are characteristic features of modern semi-arid deserts. Sandflats are deposited during periodic floods or high lake levels but are commonly dry for much of the time, permitting aeolian reworking of the sediment. Sandsheets can develop in such situations, typically where there is limited sand supply and the water table relatively high, but the formation of large dunes is restricted by periods of flooding (Kocurek \& Neilsen 1986; Kocurek 1996).

Brookfield (2004, p. 289) recorded palaeocurrent directions ranging from south-east through south to west, whereas the limited work carried out here suggests cross-bedding azimuths dip to the north-west for the aeolian facies and to the west for the fluvial facies. Aeolian cross-beds dipping to the NW would fit the global pattern of NE or E tradewinds that are well known from the Permian (Glennie 1972) and probably continued into the Triassic. An alternative could be that these cross-beds developed from winds, unless they were being convected up a wadi towards 
a palaeo-high (K W Glennie, pers comm.). Sandstones exhibiting similar alternating fluvial and aeolian lithofacies can be seen in Carwinley Burn [NY 403 729] and are thought to be at a stratigraphical position comparable to those in the River Lyne described above. The alternation of fluvial and softer, aeolian deposits at these localities is thought to be an example of the strata described by Trotter \& Hollingworth (1932) as 'transitional' between the St Bees Sandstone and Kirklinton Sandstone. As noted previously, Brookfield (2004) excluded these strata from the Kirklinton Sandstone and placed them in the upper part of his Annan Sandstone.

\section{Upper part of the Kirklinton Sandstone Formation}

The sandstones in the River Lyne at Cliff Bridge [NY 4136 6619], and nearby in Hether Burn, were thought by Holmes (1881) to be among the best exposures of the Kirklinton Sandstone Formation (Fig. 12). Close by, they are conformably overlain by argillaceous rocks of the MMG, demonstrating that the outcrops are towards the top of the Kirklinton Sandstone. Significant exposures of similar sandstones occur at several localities, e.g. Redkirk Point [NY 3023 6507], Rockcliffe [NY 3555 6183] and Longtown [NY 379 689] (Holmes 1899; Dixon et al. 1926; Trotter \& Hollingworth 1932; Brookfield 2004). It is only these higher strata that Brookfield (2004) included in his restricted Kirklinton Sandstone.

Although there is some lithological variation from locality to locality, these sandstones are characteristically fine to medium-grained, orange brown, feldspathic, moderately to well sorted, with common, well-rounded, coarse to very coarse, frosted grains (Fig. 13). The rocks are generally soft and friable, and seem to have been little quarried. In thin section they are highly porous (Fig. 13). At several localities, notably Cliff Bridge, the sandstones typically comprise large (up to $2 \mathrm{~m}$ ) trough cross-bedded sets with swept-out toesets (Fig. 12). There are also numerous smaller scale sets, 0.1-0.5 m in thickness. Locally, asymmetrical ripple-form sets, with no internal foreset lamination, occur on toesets and some have thin clay drapes. Typically, mica 
and clay are absent from the sandstones, and this together with the common coarse, frosted grains, serve to distinguish these rocks from the St Bees Sandstone and the lower parts of the Kirklinton Sandstone. A section at Rockcliffe exposes $c .4 \mathrm{~m}$ of pinkish brown to orange-brown very fine- to fine-grained sandstones that are typically dominated by small-scale trough crossbedding, in sets that range from 10 to $20 \mathrm{~cm}$, rarely up to $40 \mathrm{~cm}$, in thickness (Figs 14, 15). Interestingly, subangular grains (Fig. 16) are common and these sandstones are generally not as well sorted as those at Cliff Bridge.

The strata at Cliff Bridge are interpreted as aeolian dune facies, with the asymmetrical ripple form sets in the toesets inferred to be wind ripples. These structures suggest that the palaeowind was from the NE. At Rockcliffe, foreset dips in smaller dune sets imply a wind blowing from east to west. An aeolian origin is also inferred at the other localities named above, although, as at Rockcliffe, large dune sets may not be present.

\section{Discussion}

The field observations described above suggest that the SSG north and east of Carlisle can be divided into three distinct lithological and sedimentological units. The principal, most readily recognised, contrast is between the generally coarser sandstones of the upper aeolian division, with more rounded grains, and largely devoid of clay and mica, and the underlying finer grained micaceous sandstones of the lower and middle divisions that include sporadic to common mudstone interbeds (Brookfield 2004). The distinction between the lower and middle divisions is less well-defined and is based on subtle sedimentological and lithological features not always well displayed at every locality or in all weather and light conditions. The lower unit corresponds to the St Bees Sandstone Formation as previously recognised in the Carlisle area, whereas the middle and upper units generally have been mapped together as Kirklinton Sandstone Formation. More recently, Brookfield (2004) has grouped the lower and middle units as the Annan Sandstone Formation, and retained the term Kirklinton Sandstone Formation in a more restricted 
sense for the upper unit. No contacts between the subdivisions were seen during field studies and previous investigations suggest that they are not satisfactorily exposed (Dixon et al. 1926; Trotter \& Hollingworth 1932). Although previous investigators inferred gradational contacts, the evidence of the Silloth No. 1A Borehole (Fig. 3) and the seismic reflection data, as noted previously, suggests that the junctions are more probably sharp disconformities, as in west Cumbria and the East Irish Sea Basin (Barnes et al. 1994; Holliday et al. 2004).

The three divisions recognised in the SSG of the eastern part of the Carlisle Basin appear to correspond closely with the similar units recognised offshore in the EIS and Solway Firth basins (Jackson \& Johnson 1996) (Tables 3, 4), and also more broadly, with the three formations identified in west Cumbria by Barnes et al. (1994). The lower and upper units in particular closely match their inferred equivalents offshore and onshore. The relatively fine-grained nature, and inferred alternating sandflat/sandsheet environments, of the Carlisle Basin middle unit is also similar to contemporary strata (Calder Sandstone Member) offshore in the East Irish Sea and Solway Firth basins described by Jackson et al. (1995), Jackson \& Johnson (1996) and Chadwick et al. (2001), although it is significantly different from the equivalent, coarser grained Calder Sandstone Formation of west Cumbria (Barnes et al. 1994).

In view of these observations, there are several options available for the lithostratigraphical subdivision of the SSG of the Carlisle Basin, taking into account that the area has not been remapped in recent years and that the only surveyed geological boundaries are $c .80$ years old and based on a now discredited premise. None of these options is totally satisfactory but those considered are:

1. Show an undivided SSG (cf. Barnes et al. 1994). 
2. Ignore the new information and follow the status quo, showing the St Bees Sandstone and Kirklinton Sandstone as mapped by previous workers (Holmes 1899; Dixon et al. 1926; Trotter \& Hollingworth 1932).

3. Redefine the St Bees Sandstone (or Annan Sandstone) and Kirklinton Sandstone to match the main lithological and sedimentological change (cf. Brookfield 2004).

4. As 3) above, but either (a) employing new names or (b) adopting the current offshore classification.

Given the lack of modern mapping and the unsatisfactory basis for the recognition of the only mapped boundary within the SSG, at the base of the Kirklinton Sandstone Formation, Option 1 should be seriously considered. However, its adoption could be seen as a major step backwards, with new geological maps showing less detail than the old, and it would leave large areas of maps with little form or indication of structure. Option 2, keeping existing linework, would provide some form to the maps, even if the basis on which the formations are divided is invalid. Options 3 and 4 have the advantage that they would attempt to show real lithological differences. Option 3 recognises the main lithological changes but retains the old, St Bees (or Annan) and Kirklinton sandstones terminology as proposed by Brookfield (2004). However, the various uses of these terms, particularly "Kirklinton Sandstone", in the past by previous workers has led to confusion likely to be compounded by their use with new definitions. If that argument were accepted, then option 4(a), introducing totally new names with no previous connotations, would be a better choice, though nominating type sections could be problematical. Option 4(b) has the merit of not requiring new names, and would apply to the Carlisle Basin essentially the same classification (St Bees Sandstone Formation overlain by Ormskirk Sandstone Formation) as that of the adjacent East Irish Sea and Solway Firth offshore basins. Although the SSG onshore in the Carlisle Basin, at 250-525 m thick, is significantly thinner than in much of the offshore area (e.g. c. $1250 \mathrm{~m}$ in Borehole 112/15-1, Fig. 3), the close lithological similarities with the East Irish Sea 
and Solway Firth basins (Fig. 3), support the view that the St Bees Sandstone and Ormskirk Sandstone formations are formational terms in the Carlisle Basin, particularly as there is continuity of outcrop between the basins, albeit in part $(c .20 \mathrm{~km})$ subsea. Another advantage is that both formations already have formally defined type sections (Barnes et al. 1994; Jackson \& Johnson 1996) with numerous reference sections. Thus Option 4(b) is thought to provide the most practical way forward and is the recommended method of subdivision of the SSG in the Carlisle area (Table 4).

Barrett (1942) and later workers found little justification for the local lithostratigraphical units within the Annan Sandstone (St Bees Sandstone) proposed by Horne \& Gregory (1916). However, as noted, equivalents of the offshore members of the St Bees Sandstone Formation, the Rottington Sandstone and Calder Sandstone members, have been recognised subsurface in the Carlisle Basin (Fig. 3). At surface, the Rottington Sandstone Member appears to be the St Bees Sandstone Formation of previous mapping with the Calder Sandstone Member equivalent to the lower part of the Kirklinton Sandstone, the boundary probably being close to the current base Kirklinton Sandstone line (Table 4). Type sections for the Rottington Sandstone Member and Calder Sandstone Member have already been designated (Jackson \& Johnson 1996). Jackson \& Johnson (1996) and Chadwick et al. (2001) recognised four subdivisions of the Calder Sandstone Member (CR1-4) in the East Irish and Solway Firth basins, principally defined by wireline log patterns. These units may also be present in the Silloth No. 1A Borehole (Fig. 3) but cannot yet be recognised at outcrop.

The three main subdivisions of the SSG, recognised in the Carlisle Basin and adjacent offshore, are probably also present in the Vale of Eden. However, this remains to be confirmed on the ground and may be difficult to demonstrate because of extensive superficial cover and structural displacement. Previous studies in this area have shown that the lower beds of the group are of identical lithofacies 
and continuous with the outcrop of the lower (Rottington Sandstone Member) part of the St Bees Sandstone Formation of the Carlisle Basin (Trotter \& Hollingworth 1932; Burgess \& Holliday 1979; Arthurton \& Wadge 1981). The highest outcrops of the group comprise lithologies typical of the Ormskirk Sandstone Formation elsewhere in NW England (Goodchild 1893; Arthurton \& Wadge 1981).

As noted above, the relatively coarse grain size of the Calder Sandstone Formation of west Cumbria is the main exception to the general similarity in sequence and lithofacies in the SSG in the basins surrounding the Lake District. A possible explanation for the coarser grain size may be the input of locally sourced material from the Lake District. This would be consistent with the observed easterly and north-easterly palaeowind directions (Jones \& Ambrose 1994). It is interesting to note in this context that preliminary studies of chrondite-normalised rare earth element (RRE) distribution patterns in the lower part of the SSG of west Cumbria suggest periods of sediment provenance from the Lake District during the deposition of the St Bees Sandstone Formation and the lower part of the Calder Sandstone Formation (Akhurst et al. 1997, pp. 81-82). Further work is required to confirm such conclusions and to identify the source of the medium to coarse-grained quartz in the Calder Sandstone Formation.

\section{Conclusions}

1. The most practical solution to current problems of lithostratigraphical subdivision of the SSG in the Carlisle Basin is to adopt the nomenclature presently employed in the contiguous offshore Solway Firth and East Irish Sea basins, where two formations are recognised, the St Bees Sandstone Formation below and the Ormskirk Sandstone Formation above. This recommendation highlights the essential similarity of the Carlisle SSG sequence with adjacent areas and brings its lithostratigraphical subdivision into conformity with a wide area of nearby NW England and adjacent offshore areas. 
2. The St Bees Sandstone is typically very fine- to fine-grained, locally medium-grained, commonly micaceous, subfeldspathic-arenite, with mudstone and siltstone interbeds and partings. It is dominantly of fluvial origin but numerous aeolian beds occur in its upper part.

3. The Ormskirk Sandstone Formation is a subfeldspathic-arenite, typically fine- to mediumgrained, commonly with coarse to very coarse rounded grains. Mica and mudstone are very rare to absent. In exposures seen in the Carlisle Basin it is dominantly of aeolian origin.

4. The Kirklinton Sandstone of Holmes $(1881,1899)$ was not adequately defined and has been a source of confusion. The formation, as mapped, includes sandstones of contrasting lithologies and depositional environments, as recognised by Dixon et al. (1926) and Trotter \& Hollingworth (1932). The main lithological change within the SSG occurs within the Kirklinton Sandstone.

5. The mapped base of the Kirklinton Sandstone is probably close to the boundary between the Rottington Sandstone and Calder Sandstone members of the St Bees Sandstone Formation.

5. These conclusions have implications for the Vale of Eden Basin where only the St Bees Sandstone Formation is presently recognised. From the published descriptions of Goodchild (1893) and Arthurton \& Wadge (1981), it seems that the Ormskirk Sandstone lithologies are present here also.

6. The relatively coarse-grained nature of the Calder Sandstone Formation of west Cumbria may indicate a significant input of locally-derived detritus in this unit.

\section{Acknowledgements}

The authors would like to thank Drs D. Millward and G.K. Lott of BGS for their encouragement and support. Mr D.I. Jackson (formerly BGS, Edinburgh) is thanked for valuable discussion and comment. The investigation was much assisted by Dr M.E. Brookfield (University of Guelph, Canada) who freely provided us with his advice and the results of his more extensive investigations of these outcrops over many years. Messrs. K. Ambrose and M.A.E. Browne 
(BGS) and Dr K.W. Glennie are thanked for constructive review of the draft manuscript. The paper is published by permission of the Executive Director, British Geological Survey (NERC).

\section{References}

AKHURST, M.C., CHADWICK, R.A., HOLLIDAY, D.W., MCCORMAC, M., MCMILLAN, A.A., MILLWARD, D. \& YOUNG, B. 1997. Geology of the west Cumbria district. Memoir of the British Geological Survey, Sheets 28, 37 and 47 (England and Wales).

ARTHURTON, R.S., BURGESS, I.C. \& HOLLIDAY, D.W. 1978. Permian and Triassic. In Moseley, F. (ed.) The geology of the Lake District. Yorkshire Geological Society Occasional Publication, 3, 189-206.

ARTHURTON, R.S. \& WADGE, A.J. 1981. Geology of the country around Penrith. Memoir of the Geological Survey of Great Britain, Sheet 24 (England and Wales).

BARNES, R.P. AMBROSE, K., HOLLIDAY, D.W. \& JONES N.S. 1994. Lithostratigraphical subdivision of the Triassic Sherwood Sandstone Group in west Cumbria. Proceedings of the Yorkshire Geological Society, 50, 51-60.

BARRETT, B.H. 1942. The Triassic rocks of the Annan Basin, Dumfriesshire. Transactions of the Geological Society of Glasgow, 20, 161-179.

BOWDEN, R.A., BUMPUS, C. \& LITTLEBOY, A.K. 1998. An overview and update of the site characterization studies at Sellafield. Proceedings of the Yorkshire Geological Society, 52, 125-137.

BRITISH GEOLOGICAL SURVEY 1995. Maryport. England and Wales Sheet 22. 1:50 000. Ordnance Survey for British Geological Survey.

BRITISH GEOLOGICAL SURVEY 1997. Cockermouth. England and Wales Sheet 84. 1:50 000. Ordnance Survey for British Geological Survey. 
BRITISH GEOLOGICAL SURVEY 1998. Kirkbean. Scotland Sheet 6W. Solid Geology. 1:50 000. (British Geological Survey: Keyworth, Nottingham.).

BRITISH GEOLOGICAL SURVEY 1998. Kirkbean. Scotland Sheet 6W. Solid Geology. 1:50 000. (British Geological Survey: Keyworth, Nottingham.).

BRITISH GEOLOGICAL SURVEY 1999. Gosforth. England and Wales Sheet 37. Solid Geology. 1:50 000. (British Geological Survey: Keyworth, Nottingham.).

BROOKFIELD, M.E. 2004. The enigma of fine-grained alluvial basin fills: the Permo-Triassic (Cumbrian Coastal and Sherwood Sandstones Groups) of the Solway Basin, NW England and SW Scotland). International Journal of Earth Sciences (Geologische Rundschau), 93, 282-296.

BURGESS, I.C. \& HOLLIDAY, D.W.1979. Geology of the country around Brough-underStainmore. Memoir of the Geological Survey of Greta Britain, Sheet 31 (England and Wales).

BURLEY, S.D. 1984. Patterns of diagenesis in the Sherwood Sandstone Group (Triassic), United Kingdom. Clay Minerals, 19, 403-440.

BUSHELL, T.P. 1986. Reservoir geology of the Morecambe Field. In Brooks, J., Goff, J.C. \& Van Hoorn, B. (eds) Habitat of Palaeozoic gas in northwest Europe. Geological Society of London Special Publication, 23, 189-208

CHADWICK, R.A., HOLLIDAY. D.W., HOLlOWAY, S. \& HULBERT, A.G. 1995. The structure and evolution of the Northumberland-Solway Basin. Subsurface Memoir of the British Geological Survey.

CHADWICK, R.A., JACKSON, D.I., BARNES, R.P., KIMBELL, G.S., JOHNSON, H., CHIVERRELL, R.C., THOMAS, G.S.P., JONES, N.S., RILEY, N.J., PICKETT, E.A., YOUNG, B., HOLLIDAY, D.W., BALL, D.F., MOLYNEUX, S.G., LONG, D., POWER, G.M. \& ROBERTS, D.H. 2001. Geology of the Isle of Man and its offshore area. British Geological Survey Research Report, RR/01/06.

COLTER, V.S. 1978. Exploration for gas in the Irish Sea. Geologie en Mijnbouw, 57, 503-516. 
COLTER, V.S. 1997. The East Irish Sea Basin - from caterpillar to butterfly, a thirty-year metamorphosis. 1-9 in Meadows, N.S., Trueblood, S.P., Hardman, M. \& Cowan, G. (eds) Petroleum Geology of the Irish sea and adjacent areas. Special Publication of the Geological Society, London 124.

COLTER, V.S. \& BARR, K.W. 1975. Recent developments in the geology of the Irish Sea and Cheshire Basins. In Woodland, A.W. (ed) Petroleum and the Continental Shelf of North-west Europe, Vol. 1, Geology. Applied Science Publishers, London, 61-75.

COWAN, G. 1993. Identification and significance of aeolian deposits within the dominantly fluvial Sherwood Sandstone Group of the East Irish Sea Basin, UK. In North, C.P. \& Prosser, D.J. (eds) Characterization of fluvial and aeolian reservoirs. Special Publication of the Geological Society, London, 73, 231-245.

COWAN G., OTTESEN, C. \& STUART, I.A. 1993. The use of dipmeter logs in the structural interpretation and palaeocurrent analysis of Morecambe Fields, East Irish Sea Basin. In Parker, J.R (ed) Petroleum geology of north-west Europe: Proceedings of the 4th Conference. Geological Society (London), 867-882.

DAY, J.B.W. 1970. Geology of the country around Bewcastle. Memoir of the Geological Survey of Great Britain, Sheet 12 (England and Wales).

DIXON, E.E.L., MADEN, J., TROTTER, F.M., HOLLINGWORTH, S.E. \& TONKS, L.H. 1926. The geology of the Carlisle, Longtown and Silloth district. Memoir of the Geological Survey of Great Britain, Sheets 11, 16 and 17 (England and Wales).

EASTWOOD, T. 1930. The geology of the Maryport district. Memoir of the Geological Survey of Great Britain, Sheet 22 (England and Wales).

EASTWOOD, T., DIXON, E.E.L., HOLLINGWORTH, S.E. \& SMITH, B. 1931. Geology of the Whitehaven and Workington District. Memoir of the Geological Survey of Great Britain, Sheet 28 (England and Wales). 
EBBERN, J. 1981. The geology of the Morecambe Gas Field. In Illing, L.V. \& Hobson, G.D. (eds) Petroleum Geology of the continental shelf of north-west Europe. Institute of Petroleum, London, 485-493.

GLENNIE, K.W. 1972. Permian Rotliegendes of Northwest Europe interpreted in light of modern desert sedimentation studies. American Association of Petroleum Geologists Bulletin, 56, 1048-1071.

GOODCHILD, J.G. 1893. Observations on the New Red Series of Cumberland and Westmorland, with special reference to classification. Transactions of the Cumberland and Westmorland Association for the Advance of Literature and Science, 17, 1-24.

GREGORY, J.W. 1915a. A deep bore at Seascale in Cumberland. Geological Magazine, 52, 146-149.

GREGORY, J.W. 1915b. The Solway Basin and its Permo-Triassic sequence. Geological Magazine, 52, 241-249.

HARKNESS, R. 1862. On the sandstones and their associated deposits in the Vale of Eden, the Cumberland Plain, and the south-east of Dumfriesshire. Quarterly Journal of the Geological Society, London, 18, 205.

HOLLIDAY, D.W., WARRINGTON, G., BROOKFIELD, M.E., MCMILLAN, A.A \& HOLLOWAY S. 2001. Permo-Triassic rocks in boreholes in the Annan-Canonbie area, Dumfries and Galloway, southern Scotland. Scottish Journal of Geology, 37, 97-113.

HOLLIDAY, D.W., HOLlOWAY, S., McMILlAN, A.A., JONES, N.S., WARRINGTON, G., \& AKHURST, M.C. 2004. The evolution of the Carlisle Basin, NW England and SW Scotland. Proceedings of the Yorkshire Geological Society, 55, 1-19.

HOLLIDAY, D.W., JONES, N.S., MCMILLAN, A.A. \& BROOKFIELD, M.E. 2005. Lithostratigraphical subdivision of the Sherwood Sandstone Group (Triassic) of the northeastern part of the Carlisle Basin, Cumbria, and adjacent parts of Dumfries and Galloway, UK. British Geological Survey Internal Report, IR/05/148. 
HOLMES, T.V. 1881. The Permian, Triassic and Liassic rocks of the Carlisle Basin. Quarterly Journal of the Geological Society, London, 37, 286-298.

HOLMES, T.V. 1899. The geology of the country around Carlisle. Memoir of the Geological Survey of Great Britain, Sheet 17 (England and Wales).

HORNE, J \& GREGORY, J W. 1916. The Annan Red Sandstone Series of Dumfriesshire. Transactions of the Geological Society of Glasgow, 15, 374-386.

JACKSON, D.I., MULHOLLAND, P., JONES, S.M. \& WARRINGTON, G. 1987. The geological framework of the East Irish Sea Basin. In Brooks, J. \& Glennie, K. (eds) Petroleum Geology of North-west Europe. Graham and Trotman, London, 191-203.

JACKSON, D.I., JACKSON, A.A., EVANS, D., WINGFIELD, R.T.R., BARNES, R.P. \& ARTHUR, M.J. 1995. United Kingdom offshore regional report: the geology of the Irish Sea. HMSO for the British Geological Survey, London.

JACKSON, D.I. \& JOHNSON, H. 1996. Lithostratigraphic nomenclature of the Triassic, Permian and Carboniferous of the UK offshore East Irish Sea Basin. British Geological Survey, Nottingham.

JONES, N.S. \& AMBROSE, K.1994. Triassic sandy braidplain and aeolian sedimentation, the Sherwood Sandstone Group, west Cumbria. Proceedings of the Yorkshire Geological Society, 50, 61-76.

KOCUREK, G. 1996. Desert aeolian systems. In: READING, H.G. (ed) Sedimentary environments: processes, facies and stratigraphy. $3^{\text {rd }}$ Edition. Blackwell Science, Oxford, 125-153.

KOCUREK, G. \& NEILSEN, J. 1986. Conditions favourable for the formation of warm-climate aeolian sand-sheets. Sedimentology, 33, 795-816.

MEADOWS, N.S. \& BEACH. A. 1993a. Structural and climatic controls on facies distribution in a mixed fluvial and aeolian reservoir: the Triassic Sherwood Sandstone Group in the Irish Sea. In North, C.P. \& Prosser, D.J. (eds) Characterization of fluvial and aeolian reservoirs. Special Publication Geological Society, London, 73. 246-264 
MEADOWS, N.S. \& BEACH. A. 1993b. Controls on reservoir quality in the Triassic Sherwood Sandstone of the Irish Sea. In Parker, J.R (ed) Petroleum geology of north-west Europe: Proceedings of the 4th Conference. Geological Society (London), 823-833.

MICHIE, U. MCL. \& BOWDEN, R.A. 1994. UK NIREX geological investigations at Sellafield. Proceedings of the Yorkshire Geological Society, 50, 5-9.

MURCHISON, R.I. \& HARKNESS, R. 1864. On the Permian rocks of the north-west of England and their extension into Scotland. Quarterly Journal of the Geological Society, London, 20, 144-165.

QUIRK, F.G., ROY, S., KNOT, I., REDFERN, J. \& HILL, L. 1999. Petroleum geology and future hydrocarbon potential of the Irish Sea. Journal of Petroleum Geology, 22, 243-260.

SEDGWICK, A, 1836. On the New Red Sandstone Series in the basin of Eden, and north-western coasts of Cumberland and Lancashire. Transactions of the Geological Society of London, $\mathbf{4}$, $383-407$.

TROTTER, F.M. \& HOLLINGWORTH, S.E. 1932. The geology of the Brampton district. Memoir of the Geological Survey of Great Britain, Sheet 18 (England and Wales).

TROTTER, F.M., HOLLINGWORTH, S.E., EASTWOOD, T. \& ROSE, W.C.C. 1937. Gosforth District. Memoir of the Geological Survey of Great Britain, Sheet 37 (England and Wales).

WARRINGTON, G., AUDLEY-CHARLES, M.G., ELLIOTT, R.E., EVANS, W.B., IVIMEYCOOK, H.C., KENT, P.E., ROBINSON, P.L., SHOTTON, F.W. \& TAYLOR, F.M. 1980. A correlation of Triassic rocks in the British Isles. Special Report of the Geological Society, London, 13.

MS. Accepted for publication 13 December 2007 
Carlisle SSG Paper -Final Revision 26 February 2008 
Captions to Figures

FIG. 1. Regional setting of the Carlisle Basin and other Permo-Triassic basins around the Irish Sea

FIG. 2. Carlisle Basin: location and simplified geological map.

FIG. 3. Subdivision of the Sherwood Sandstone Group (SSG) in offshore well 112/15-1 and the Silloth No. 1A Borehole. RSM Rottington Sandstone Member (St Bees Sandstone Formation); CSM Calder Sandstone Member (St Bees Sandstone Formation); OSF Ormskirk Sandstone Formation; CR1-4 divisions of the CSM recognised by Jackson \& Johnson (1996). All depth is metres below Kelly Bushing.

FIG. 4. Cove Quarry [NY 254 710]; c. $4 \mathrm{~m}$ high face in sheet and semi-confined sandstones, towards the base of the St Bees Sandstone Formation (Rottington Sandstone Member), looking NE.

FIG. 5. General view of Cove Quarry [NY 254 710] showing sheet sandstones near base of quarry overlain by channelised sandstones towards the base of the St Bees Sandstone Formation (Rottington Sandstone Member). View looking NW (BGS Reg. No. P621360).

FIG. 6. Photomicrograph of St Bees Sandstone, Cove Quarry [NY 254 710]. The thin section is dominated by quartz grains, although feldspar (stained yellow) forms an appreciable component (Thin section NJN107). Scale bar 200 micron.

FIG. 7. St Bees Sandstone Formation, Brampton Quarries, N of the River Gelt [NY 5287 5864], looking NNE. Note the laterally extensive erosion surfaces (often forming overhangs) spaced every few metres or so vertically.

FIG. 8. Kirklinton Sandstone exposed in c. $3 \mathrm{~m}$ section on the $\mathrm{W}$ bank of the River Lyne, Kirklinton. [NY 431 677], looking S. Note the sheet-like, thinly bedded nature of the sandstone. (BGS Reg. No. P621359). 
FIG. 9. Rippled flaggy sandstones, Kirklinton Sandstone, E bank of the River Lyne, Kirklinton [NY 431 677], looking SE (BGS Reg. No. P621361).

FIG. 10. Adhesion ripples on a bedding plane, Kirklinton Sandstone, E bank of the River Lyne, Kirklinton [NY 431 677] (BGS Reg. No. P621363).

FIG. 11. Small-scale trough cross-beds of interpreted aeolian origin, Kirklinton Sandstone, E bank of the River Lyne, Kirklinton [NY 431 677], looking NW (BGS reg. No. P621362).

FIG. 12. Large aeolian cross-beds from the upper part of the Kirklinton Sandstone, Cliff Bridge [NY 4136 6619], looking ESE.

FIG. 13. Thin section photomicrograph of the Kirklinton Sandstone at Cliff Bridge [NY 4136 6619] (Thin section NJN104). The sandstone is fine-grained, moderately to well sorted with distinct well rounded coarse grains giving a bimodality to the grain size. The blue dye indicates void space and shows that the sandstone is highly porous. Scale bar 200 micron.

FIG. 14. General view of the Kirklinton Sandstone at Rockcliffe [NY 3555 6183], looking N.

FIG. 15. Close-up of the Kirklinton Sandstone at Rockcliffe [NY 3555 6183], looking N. Note the sandstone predominantly comprises trough cross-bedding, in sets $10-30 \mathrm{~cm}$ in size.

FIG. 16. Thin section photomicrograph of the Kirklinton Sandstone at Rockcliffe [NY 3555 6183] (Thin secton NJN106). This is a fine- to medium-grained sandstone. Note the poor sorting and subangular nature of many of the framework grains (largely quartz). Feldspars are stained yellow. Scale bar 200 micron.

Captions to Tables 
TABLE 1 Evolution of lithostratigraphical classification of Triassic sandstones in the Carlisle and Vale of Eden basins

TABLE 2 Evolution of lithostratigraphical classification of Triassic sandstones in the East Irish Sea Basin

TABLE 3 Summary of the current lithostratigraphical subdivision of the Sherwood Sandstone Group and associated strata in Cumbria

TABLE 4. Suggested new subdivision of the Sherwood Sandstone Group in the Carlisle Basin 
Table 1 Evolution of lithostratigraphical classification of Triassic sandstones in the Carlisle and Vale of Eden basins

\begin{tabular}{|c|c|c|c|c|c|c|}
\hline $\begin{array}{c}\text { Holmes (1881, } \\
1899)\end{array}$ & $\begin{array}{l}\text { Goodchild (1893); } \\
\text { Gregory (1915b) }\end{array}$ & $\begin{array}{l}\text { Dixon et al. } \\
\quad(1926)\end{array}$ & \multicolumn{2}{|c|}{$\begin{array}{l}\text { Arthurton et al. (1978); } \\
\text { Warrington et al. } \\
\text { (1980) }\end{array}$} & $\begin{array}{l}\text { Brookfield } \\
\text { (2004) }\end{array}$ & $\begin{array}{l}\text { Barnes et al. (1994); } \\
\text { Akhurst et al. (1997) }\end{array}$ \\
\hline Stanwix Shales & Stanwix Shales & Stanwix Shales & \multicolumn{2}{|c|}{$\begin{array}{l}\text { Mercia Mudstone Group } \\
\text { (Stanwix Shales) }\end{array}$} & $\begin{array}{l}\text { Stanwix } \\
\text { Shales } \\
\end{array}$ & $\begin{array}{c}\text { Mercia Mudstone } \\
\text { Group (Stanwix Shales) }\end{array}$ \\
\hline $\begin{array}{l}\text { Kirklinton } \\
\text { Sandstone }\end{array}$ & \multirow[t]{2}{*}{ Kirklinton Sandstone } & $\begin{array}{l}\text { Kirklinton } \\
\text { Sandstone }\end{array}$ & $\begin{array}{l}\text { Kirklinton } \\
\text { Sandstone } \\
\text { Formation }\end{array}$ & \multirow{4}{*}{$\begin{array}{l}\text { Sherwood } \\
\text { Sandstone } \\
\text { Group }\end{array}$} & $\begin{array}{l}\text { Kirklinton } \\
\text { Sandstone }\end{array}$ & $\begin{array}{l}\text { Ormskirk Sandstone } \\
\text { Formation equivalent* }\end{array}$ \\
\hline $\begin{array}{c}\text { Upper Gypsiferous } \\
\text { Shales }\end{array}$ & & ?? ????? ? & ???? & & $\begin{array}{c}\text { Annan } \\
\text { Sandstone }\end{array}$ & $\begin{array}{l}\text { Calder Sandstone } \\
\text { Formation } \\
\text { equivalent* }\end{array}$ \\
\hline & \multirow[b]{2}{*}{ St Bees Sandstone } & \multirow[b]{2}{*}{ St Bees Sandstone } & \multirow{2}{*}{$\begin{array}{l}\text { St Bees } \\
\text { Sandstone } \\
\text { Formation }\end{array}$} & & & \\
\hline St Bees Sandstone & & & & & & $\begin{array}{l}\text { St Bees Sandstone } \\
\text { Formation }\end{array}$ \\
\hline $\begin{array}{c}\text { Lower Gypsiferous } \\
\text { Shales }\end{array}$ & Gypsiferous Shales & St Bees Shales & \multicolumn{2}{|c|}{$\begin{array}{c}\text { St Bees Shale/Eden Shales } \\
\text { formations } \\
\end{array}$} & Eden Shales & $\begin{array}{l}\text { St Bees Shale/Eden } \\
\text { Shales formations }\end{array}$ \\
\hline
\end{tabular}

* Identified so far in subsurface only

Table 2 Evolution of lithostratigraphical classification of Triassic sandstones in the East Irish Sea Basin

\begin{tabular}{|c|c|c|c|c|c|c|c|}
\hline \multirow[t]{2}{*}{$\begin{array}{l}\text { Gregory } \\
(1915 a) \\
\text { [onshore] }\end{array}$} & $\begin{array}{l}\text { Eastwood } \\
\quad \text { et al. } \\
\text { (1931); } \\
\text { Trotter } \text { et } \\
\text { al. }(1937) \\
\text { [onshore] }\end{array}$ & $\begin{array}{l}\text { Colter (1978); } \\
\text { Ebbern }(1981) \\
\text { [offshore] }\end{array}$ & \multicolumn{2}{|c|}{$\begin{array}{l}\text { Jackson } \text { et al. (1987) } \\
\text { [offshore] }\end{array}$} & $\begin{array}{l}\text { Barnes et al. } \\
\text { (1994); Akhurst } \\
\text { et al. (1997) } \\
\text { [onshore] }\end{array}$ & \multicolumn{2}{|c|}{$\begin{array}{c}\text { Jackson \& Johnson } \\
\text { (1996); Chadwick et al. } \\
\text { (2001) } \\
\text { [offshore] }\end{array}$} \\
\hline & & $\begin{array}{l}\text { Mercia Mudstone } \\
\text { Group }\end{array}$ & \multicolumn{2}{|c|}{$\begin{array}{l}\text { Mercia Mudstone } \\
\text { Group }\end{array}$} & & \multicolumn{2}{|c|}{ Mercia Mudstone Group } \\
\hline \multirow{3}{*}{$\begin{array}{l}\text { Kirklinton } \\
\text { Sandstone } \\
\text { ????? }\end{array}$} & St & $\begin{array}{l}\text { Keuper Waterstones } \\
\text { Formation } \\
\end{array}$ & \multicolumn{2}{|c|}{$\begin{array}{l}\text { Ormskirk Sandstone } \\
\text { Formation }\end{array}$} & $\begin{array}{l}\text { Ormskirk } \\
\text { Sandstone }\end{array}$ & \multicolumn{2}{|c|}{$\begin{array}{l}\text { Ormskirk Sandstone } \\
\text { Formation }\end{array}$} \\
\hline & \multirow{3}{*}{$\begin{array}{c}\text { Bees } \\
\text { Sandstone }\end{array}$} & Formation & & & & & \\
\hline & & \multirow{2}{*}{$\begin{array}{l}\text { St Bees Sandstone } \\
\text { Formation }\end{array}$} & \multirow{2}{*}{$\begin{array}{l}\text { St Bees } \\
\text { Sandstone } \\
\text { Formation }\end{array}$} & 'upper' & $\begin{array}{c}\text { Calder Sandstone } \\
\text { Formation }\end{array}$ & \multirow{2}{*}{$\begin{array}{l}\text { St Bees } \\
\text { Sandstone } \\
\text { Formation }\end{array}$} & $\begin{array}{c}\text { Calder Sst. } \\
\mathrm{Mb} .\end{array}$ \\
\hline $\begin{array}{l}\text { St Bees } \\
\text { Sandstone }\end{array}$ & & & & 'lower' & $\begin{array}{c}\text { St Bees } \\
\text { Sandstone } \\
\text { Formation } \\
\end{array}$ & & $\begin{array}{c}\text { Rottington } \\
\text { Sst. Mb. }\end{array}$ \\
\hline $\begin{array}{l}\text { Gypsiferous } \\
\text { Shales }\end{array}$ & $\begin{array}{l}\text { St Bees } \\
\text { Shales }\end{array}$ & $\begin{array}{l}\text { St Bees Shale } \\
\text { Formation }\end{array}$ & \multicolumn{2}{|c|}{$\begin{array}{l}\text { St Bees Shale } \\
\text { Formation }\end{array}$} & $\begin{array}{l}\text { St Bees Shale } \\
\text { Formation }\end{array}$ & \multicolumn{2}{|c|}{$\begin{array}{c}\text { Barrowmouth Mudstone } \\
\text { Formation }\end{array}$} \\
\hline
\end{tabular}


Table 3 Summary of the current lithostratigraphical subdivision of the Sherwood Sandstone Group and associated strata in Cumbria

\begin{tabular}{|c|c|c|c|c|c|c|c|}
\hline \multirow[t]{2}{*}{ GROUP } & \multicolumn{4}{|c|}{ EAST IRISH SEA \& SOLWAY FIRTH BASINS } & \multirow{2}{*}{\multicolumn{2}{|c|}{$\begin{array}{c}\text { CARLISLE BASIN } \\
\text { (Dixon et al. 1926; Barrett 1942; } \\
\text { Holliday et al. 2001) }\end{array}$}} & \multirow{2}{*}{$\begin{array}{c}\text { VALE OF } \\
\text { EDEN BASIN } \\
\text { (Arthurton \& } \\
\text { Wadge 1981) }\end{array}$} \\
\hline & \multicolumn{2}{|c|}{$\begin{array}{c}\text { OFFSHORE } \\
\text { (Jackson \& Johnson 1996) }\end{array}$} & \multicolumn{2}{|c|}{$\begin{array}{c}\text { ONSHORE } \\
\text { (west Cumbria) } \\
\text { (Barnes } \text { et al. 1994) }\end{array}$} & & & \\
\hline $\begin{array}{c}\text { Mercia } \\
\text { Mudstone } \\
\text { Group } \\
\end{array}$ & \multicolumn{2}{|c|}{$\begin{array}{l}\text { Mercia Mudstone Group } \\
\text { (MMG) }\end{array}$} & & & \multicolumn{2}{|c|}{ Stanwix Shales } & \\
\hline \multirow{3}{*}{$\begin{array}{l}\text { Sherwood } \\
\text { Sandstone } \\
\text { Group } \\
\text { (SSG) }\end{array}$} & \multicolumn{2}{|c|}{$\begin{array}{l}\text { Ormskirk Sandstone } \\
\text { Formation (OSF) }\end{array}$} & \multicolumn{2}{|c|}{$\begin{array}{l}\text { Ormskirk Sandstone } \\
\text { Formation (OSF) }\end{array}$} & \multicolumn{2}{|c|}{ Kirklinton Sandstone (KSF) } & $\begin{array}{l}\text { ?Kirklinton } \\
\text { Sandstone }\end{array}$ \\
\hline & \multirow{2}{*}{$\begin{array}{l}\text { St Bees } \\
\text { Sandstone } \\
\text { Formation } \\
\text { (SBSF) }\end{array}$} & $\begin{array}{l}\text { Calder } \\
\text { Sandstone } \\
\text { Member } \\
(\mathrm{CSM}) \\
\end{array}$ & \multicolumn{2}{|c|}{$\begin{array}{l}\text { Calder Sandstone } \\
\text { Formation } \\
(\mathrm{CSF})\end{array}$} & \multicolumn{2}{|c|}{ ????????? } & ?? ??? \\
\hline & & $\begin{array}{l}\text { Rottington } \\
\text { Sandstone } \\
\text { Member } \\
\text { (RSM) }\end{array}$ & \multicolumn{2}{|c|}{$\begin{array}{l}\text { St Bees Sandstone } \\
\text { Formation } \\
\text { (SBSF) }\end{array}$} & \multicolumn{2}{|c|}{$\begin{array}{l}\text { St Bees Sandstone Formation } \\
\text { (SBSF) }\end{array}$} & $\begin{array}{l}\text { St Bees } \\
\text { Sandstone } \\
\text { Formation }\end{array}$ \\
\hline \multirow{2}{*}{$\begin{array}{l}\text { Cumbrian } \\
\text { Coast } \\
\text { Group }\end{array}$} & \multicolumn{2}{|c|}{$\begin{array}{c}\text { Barrowmouth Mudstone } \\
\text { Formation }\end{array}$} & $\begin{array}{l}\text { St Bees Shale } \\
\text { Formation }\end{array}$ & $\begin{array}{l}\text { B } \\
\text { r }\end{array}$ & \multirow{2}{*}{\multicolumn{2}{|c|}{$\begin{array}{l}\text { Eden Shales } \\
\text { Formation }\end{array}$}} & \\
\hline & \multicolumn{2}{|c|}{ St Bees Evaporite Formation } & $\begin{array}{c}\text { St Bees } \\
\text { Evaporite } \\
\text { Formation }\end{array}$ & $\begin{array}{l}\mathrm{c} \\
\mathrm{k} \\
\mathrm{r} \\
\mathrm{a} \\
\mathrm{m} \\
\end{array}$ & & & Formation \\
\hline $\begin{array}{l}\text { Appleby } \\
\text { Group }\end{array}$ & & $\begin{array}{l}\text { Collyhurst } \\
\text { Sandstone } \\
\text { Formation }\end{array}$ & Brockran & & $\begin{array}{l}\text { Penrith Sandstone } \\
\text { Formation and } \\
\text { Brockram }\end{array}$ & & $\begin{array}{c}\text { Penrith } \\
\text { Sandstone and } \\
\text { Brockram }\end{array}$ \\
\hline
\end{tabular}

Table 4. Suggested new subdivision of the Sherwood Sandstone Group in the Carlisle Basin

\begin{tabular}{|c|c|c|c|}
\hline & Previous Nomenclature & \multicolumn{2}{|c|}{ Proposed Nomenclature } \\
\hline \multirow{3}{*}{$\begin{array}{c}\text { Sherwood } \\
\text { Sandstone } \\
\text { Group } \\
\text { (SSG) }\end{array}$} & \multirow{2}{*}{$\begin{array}{l}\text { Kirklinton Sandstone } \\
\text { Formation (KSF) }\end{array}$} & \multicolumn{2}{|c|}{$\begin{array}{l}\text { Ormskirk Sandstone Formation } \\
\text { (OSF) }\end{array}$} \\
\hline & & \multirow{2}{*}{$\begin{array}{l}\text { St Bees Sandstone } \\
\text { Formation (SBSF) }\end{array}$} & $\begin{array}{l}\text { Calder Sandstone } \\
\text { Member (CSM) }\end{array}$ \\
\hline & $\begin{array}{l}\text { St Bees Sandstone } \\
\text { Formation }\end{array}$ & & $\begin{array}{l}\text { Rottington Sandstone } \\
\text { Member (RSM) }\end{array}$ \\
\hline
\end{tabular}




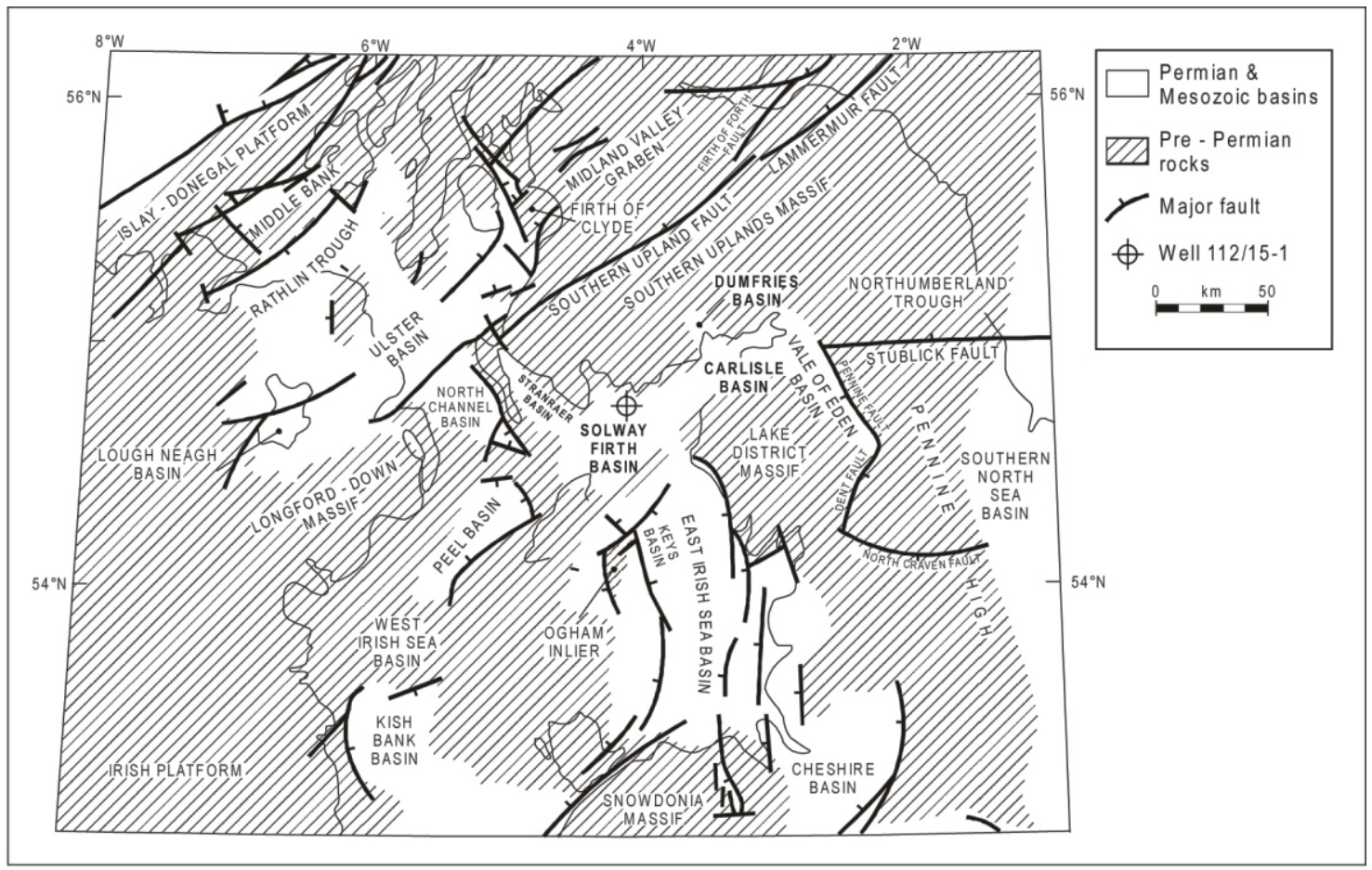

Fig. 1. Regional setting of the Carlisle Basin and other Permo-Triassic basins around the Irish Sea

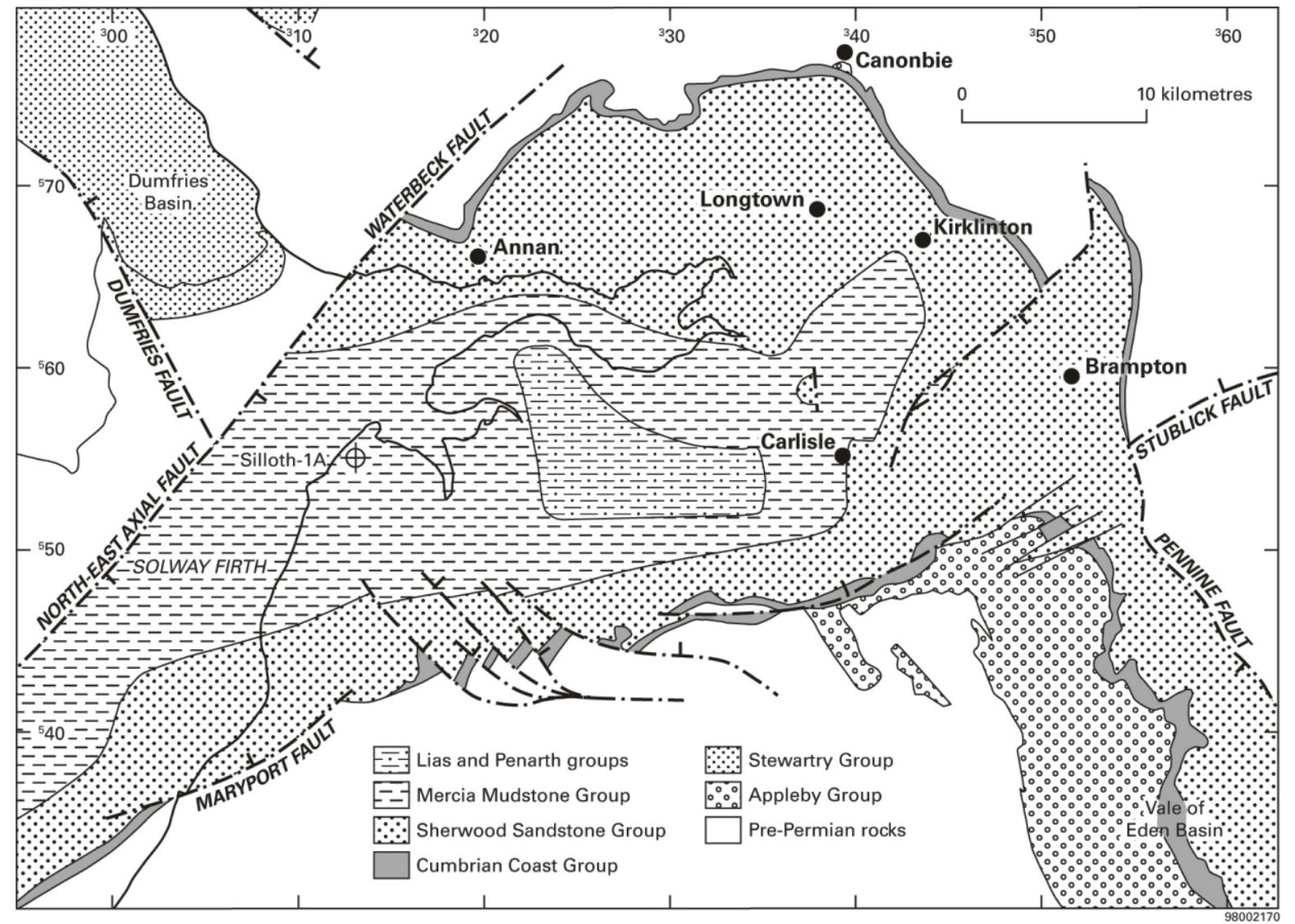

Fig. 2. Carlisle Basin; location and simplified geological map 


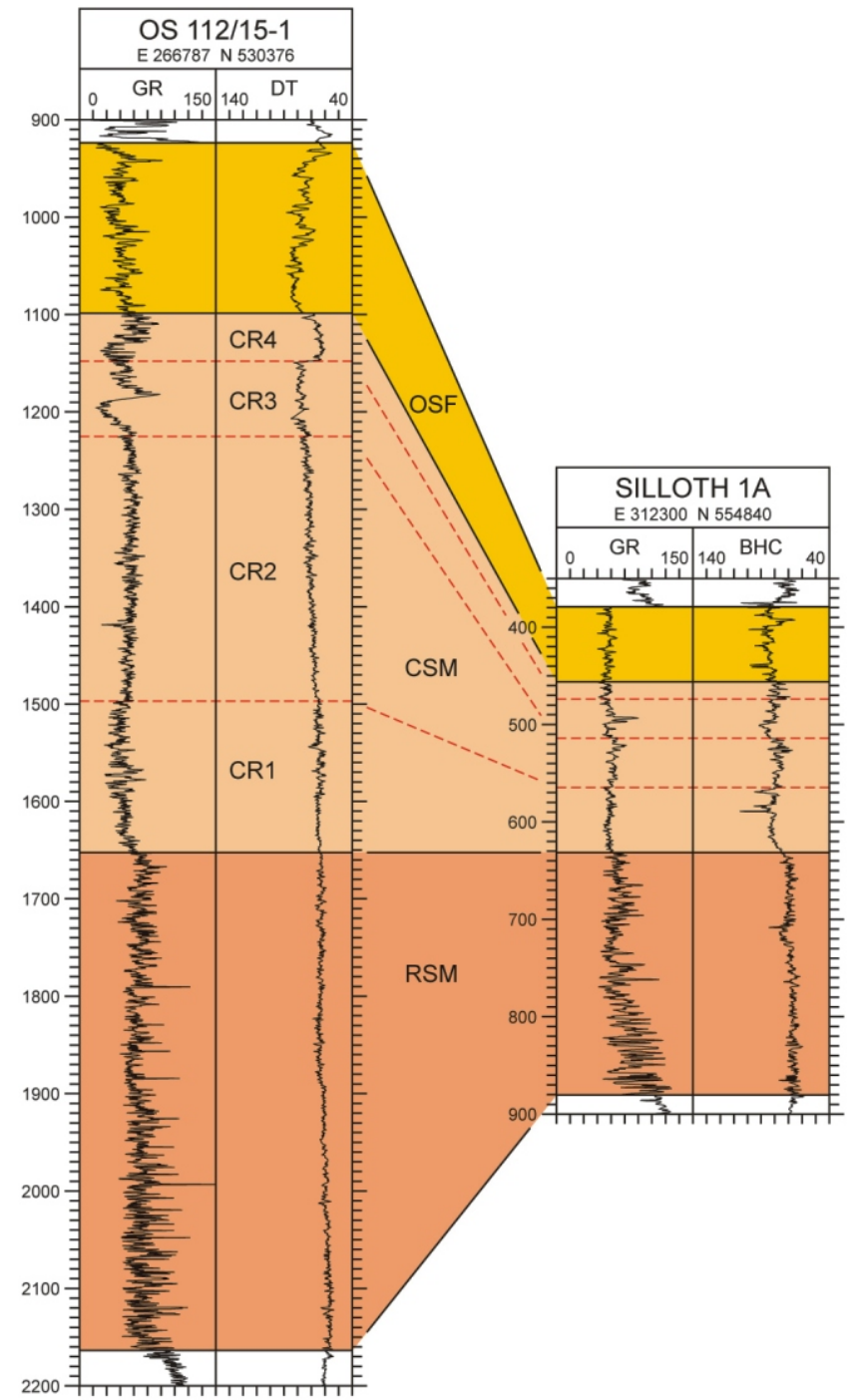

Fig. 3. Subdivision of the Sherwood Sandstone Group (SSG) in offshore well 112/15-1 and the Silloth No. 1A Borehole. RSM Rottington

Sandstone Member (St Bees Sandstone Formation); CSM Calder Sandstone Member (St Bees Sandstone Formation); OSF Ormskirk Sandstone Formation; CR1-4 divisions of the CSM recognised by Jackson \& Johnson (1996). 


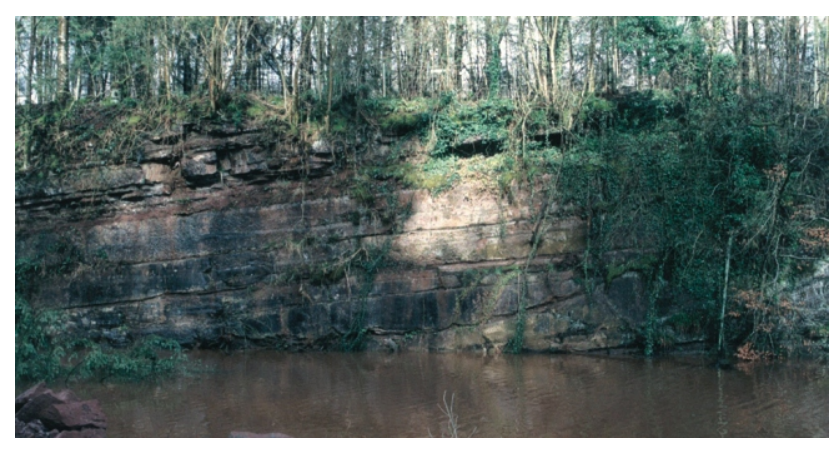

Fig. 4. Cove Quarry [NY 254 710]; c. 4 m high face in sheet and semi-confined sandstones, towards the base of the St Bees Sandstone Formation (Rottington Sandstone Member), looking NE.

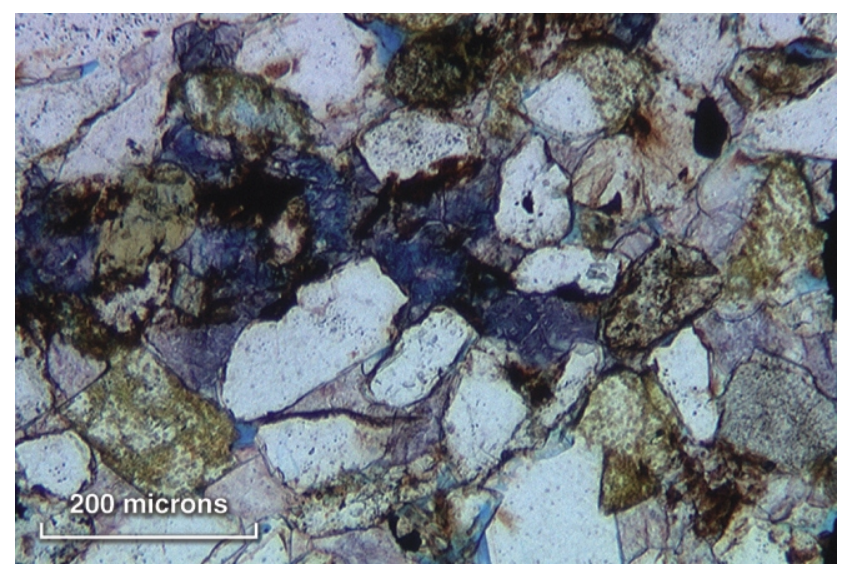

Fig. 6. Photomicrograph of St Bees Sandstone, Cove Quarry [NY 254 710]. The thin section is dominated by quartz grains, although feldspar (stained yellow) forms an appreciable component (Thin section NJN107). Scale bar 200 micron.

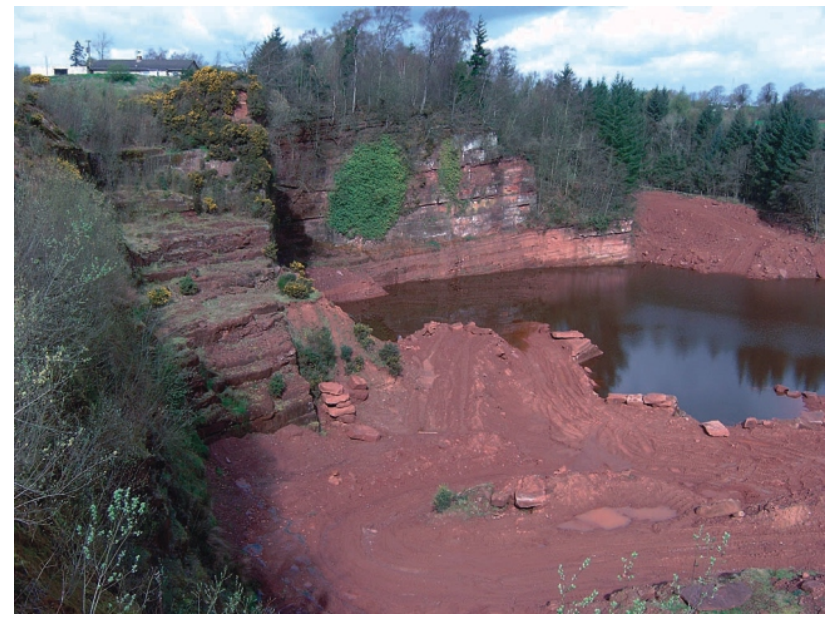

Fig. 5. General view of Cove Quarry [NY 254 710] showing sheet sandstones near base of quarry overlain by channelised sandstones towards the base of the St Bees Sandstone Formation (Rottington Sandstone Member). View looking NW (BGS Reg. No. P621360).

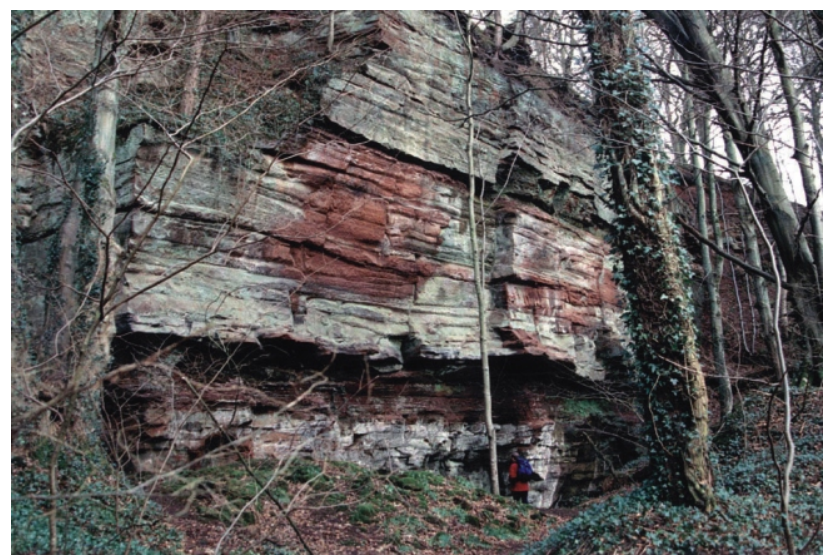

Fig. 7. St Bees Sandstone Formation, Brampton Quarries, N of the River Gelt [NY 5287 5864], looking NNE. Note the laterally extensive erosion surfaces (often forming overhangs) spaced every few metres or so vertically. 


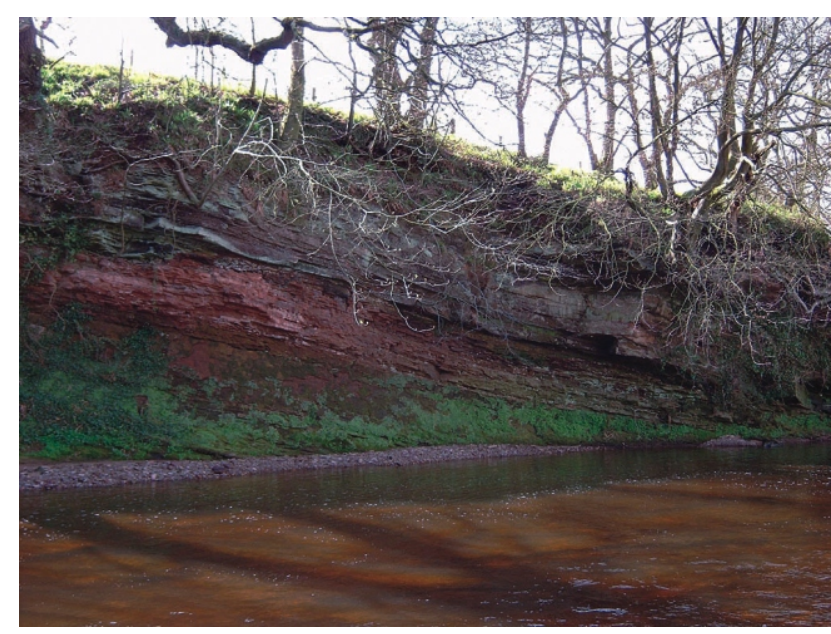

Fig. 8. Kirklinton Sandstone exposed in c. $3 \mathrm{~m}$ section on the W bank of the River Lyne, Kirklinton. [NY 431 677], looking S. Note the sheet-like, thinly bedded nature of the sandstone. (BGS Reg. No. P621359).

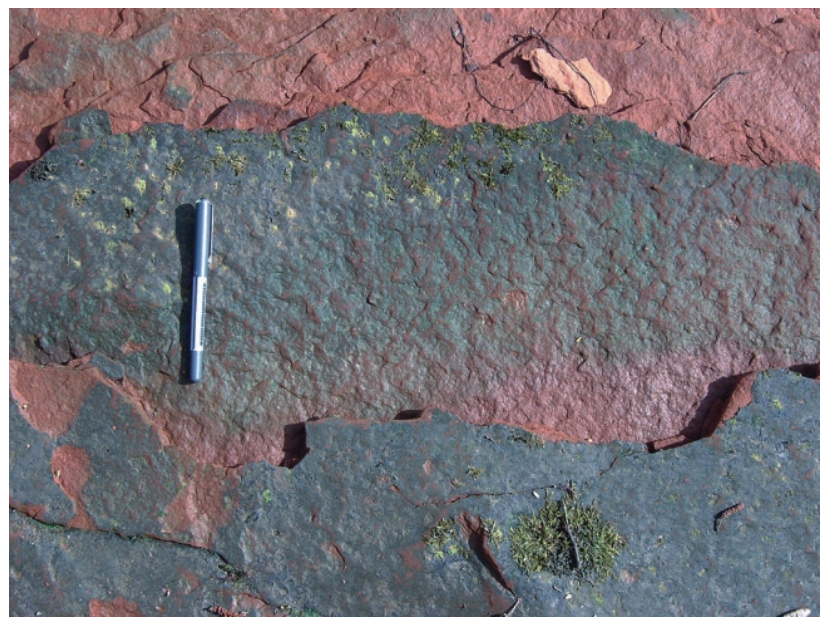

Fig. 10. Adhesion ripples on a bedding plane, Kirklinton Sandstone, E bank of the River Lyne, Kirklinton [NY 431 677] (BGS Reg. No. P621363).

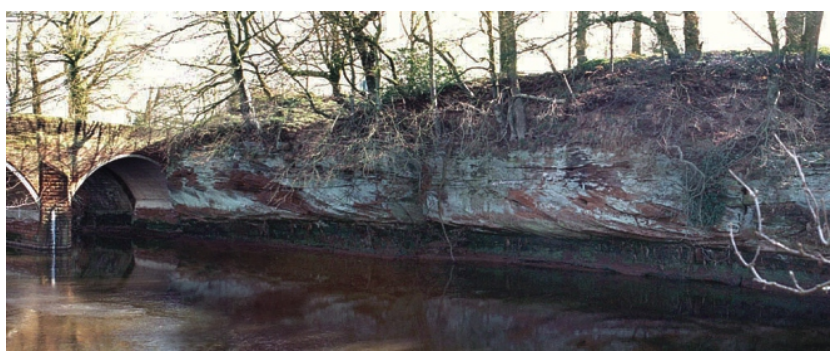

Fig. 12. Large aeolian cross-beds from the upper part of the Kirklinton Sandstone, Cliff Bridge [NY 4136 6619], looking ESE.

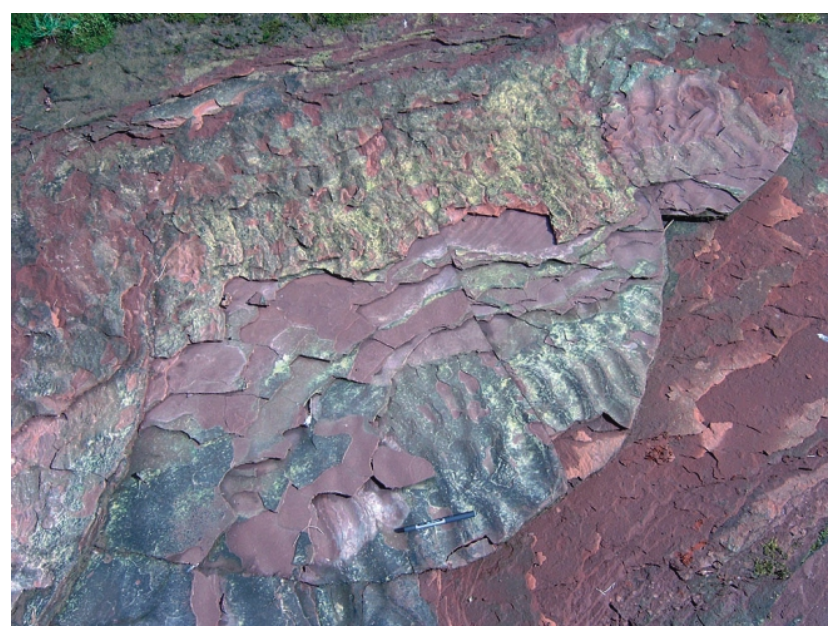

Fig. 9. Rippled flaggy sandstones, Kirklinton Sandstone, E bank of the River Lyne, Kirklinton [NY 431 677], looking SE (BGS Reg. No. P621361).

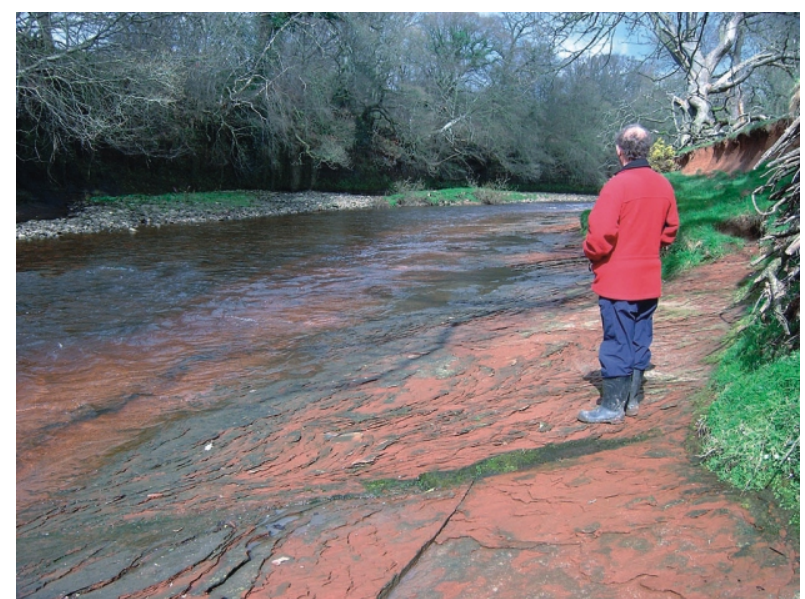

Fig. 11. Small-scale trough cross-beds of interpreted aeolian origin, Kirklinton Sandstone, E bank of the River Lyne, Kirklinton [NY 431 677], looking NW (BGS Reg. No. P621362). 


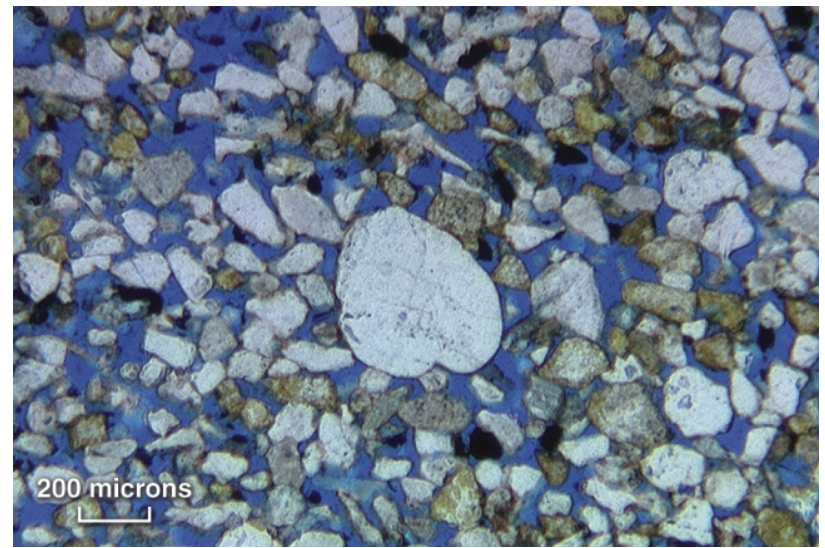

Fig. 13. Thin section photomicrograph of the Kirklinton Sandstone at Cliff Bridge [NY 4136 6619] (Thin section NJN104). The sandstone is fine-grained, moderately to well sorted with distinct well rounded coarse grains giving a bimodality to the grain size. The blue dye indicates void space and shows that the sandstone is highly porous. Scale bar 200 micron.

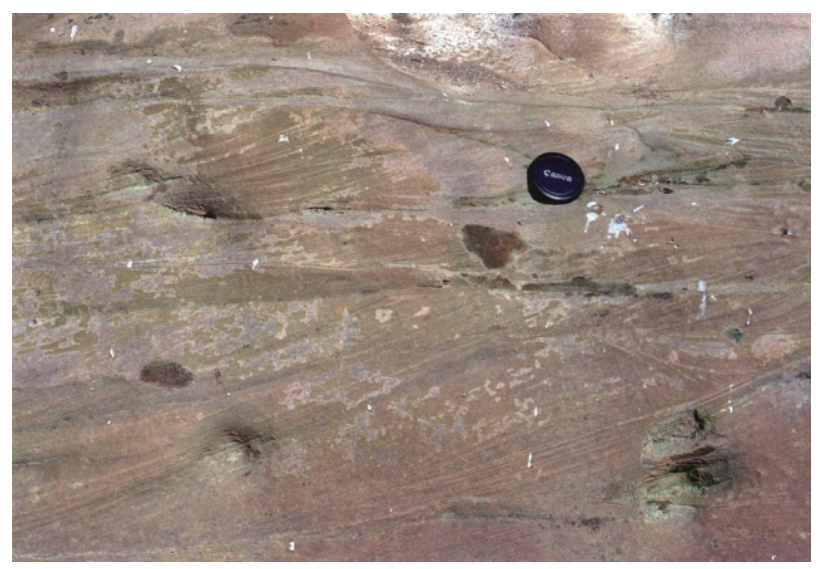

Fig. 15. Close-up of the Kirklinton Sandstone at Rockcliffe [NY 3555 6183], looking N. Note the sandstone predominantly comprises trough crossbedding, in sets $10-30 \mathrm{~cm}$ in size.

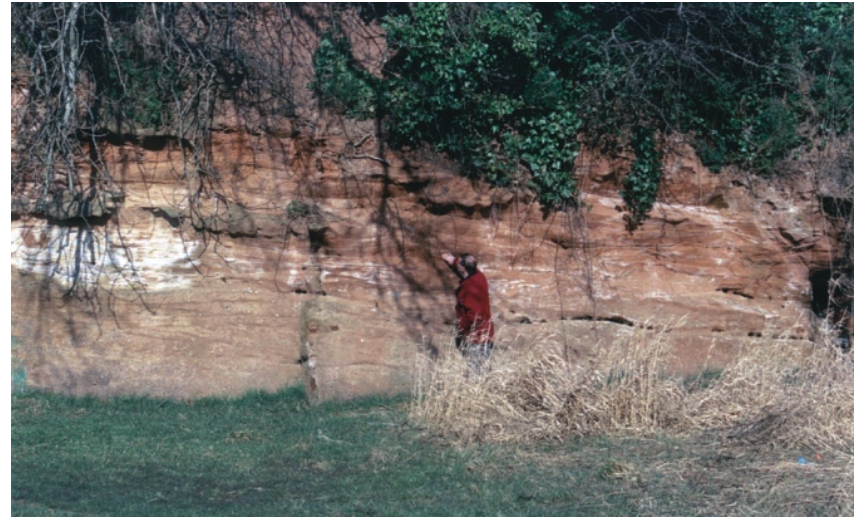

Fig. 14. General view of the Kirklinton Sandstone at Rockcliffe [NY 3555 6183], looking N.

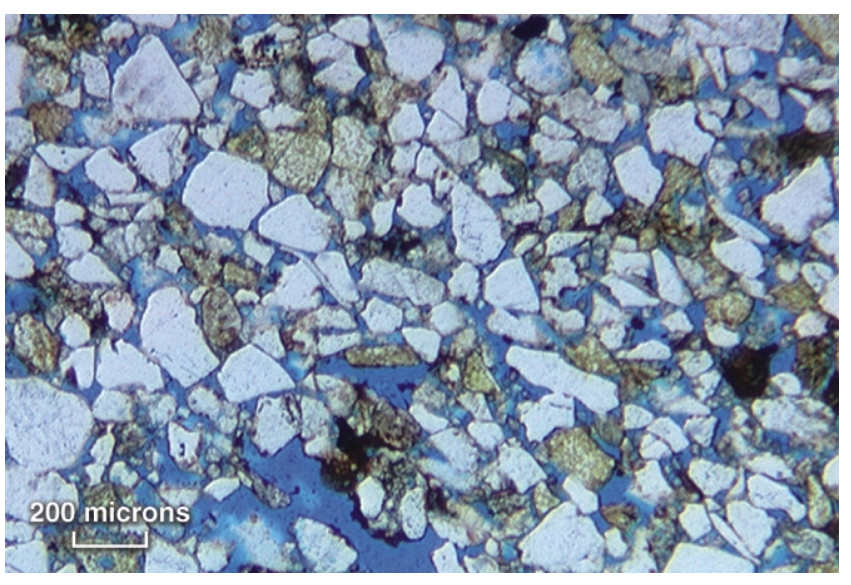

Fig. 16. Thin section photomicrograph of the Kirklinton Sandstone at Rockcliffe [NY 3555 6183] (Thin secton NJN106). This is a fine- to medium-grained sandstone. Note the poor sorting and subangular nature of many of the framework grains (largely quartz). Feldspars are stained yellow. Scale bar 200 micron 